\title{
Avian and Habitat Diversity in the Semi-Arid Lands of Baringo South, Kenya
}

\author{
George Morara Ogendi1 ${ }^{1 *}{ }^{*}$, Rhoda N. Ondieki ${ }^{2}$ \\ ${ }^{1}$ Department of Environmental Science, Egerton University, Egerton, Kenya \\ ${ }^{2}$ Dryland Research Training \& Ecotourism Centre, Chemeron, Egerton, Kenya \\ Email: ^gmorara2009@gmail.com, rhodanyasu@gmail.com
}

How to cite this paper: Ogendi, G.M. and Ondieki, R.N. (2020) Avian and Habitat Diversity in the Semi-Arid Lands of Baringo South, Kenya. Open Journal of Ecology, 10, 518-536.

https://doi.org/10.4236/oje.2020.108033

Received: June 5, 2020

Accepted: August 10, 2020

Published: August 13, 2020

Copyright $\odot 2020$ by author(s) and Scientific Research Publishing Inc. This work is licensed under the Creative Commons Attribution International License (CC BY 4.0).

http://creativecommons.org/licenses/by/4.0/

\begin{abstract}
Semi-arid wooded-shrublands are important and critical habitats that provide breeding and feeding grounds for a variety of bird species, some of which are endangered, vulnerable or threatened with extinction. Habitat type and size influence abundance and diversity of birds globally and particularly in developing countries that are characterized by rapid human population growth and haphazard urban, agricultural and industrial development. The objective of this study was to assess avian and habitat diversity at Chemeron, a semi-arid land in the northern rangelands of Kenya. The study was guided by four questions: What kind of Habitat types are present at Chemeron study area? What kind of birds are found at Chemeron area? What is the conservation status of birds found at Chemeron area? What are the functional feeding guilds of birds that are found in the study area? How does the habitat type influence bird species abundance and diversity at Chemeron? Four 2-km long transects radiating from a central point within the study area were selected for a ground survey of birds that was conducted on foot. The surveys were conducted between 06:30 and 09:30 and 16:00 and 18:00 from October 2019 to April 2020. Bird species were observed and identified to the species level using high-resolution binoculars, field guidebooks and available taxonomic keys. Our surveys documented two main habitat types: Acacia-Balanites-Boscia woodlands dominated by Acacia senegal, Acacia mellifera, Acacia nilotica, Boscia angustifolia, and Balanites aegyptica. The second kind of habitat consisted of the invasive Acalypha fruticosa and Indigofera arrecta with Acacia reficiens-Acacia brevispica overstorey. A total of 53 bird species were sighted and identified the vulnerable Yellow necked spurfowl (Francolinus leucoscepus). Seventy-nine percent of the birds were sighted as singles or in pairs except for the gregarious white browed sparrow weaver (Plocepasser mahali), Apus caffer, Numida meleagris, Streptopelia senegalensis, Dinemellia dinemelli and Corythaxoides leucogaster. Significant differences in the various
\end{abstract}


species diversity indices among the six transects were observed $(\mathrm{p}<0.05)$. Approximately $60 \%$ of the birds belong to the insectivorous and omnivorous feeding guild. Charcoal burning and uncontrolled harvesting of wood are the major threats to the avian habitats in the study area. The high diversity of bird species in the study area can be attributed to the varied diversity of habitats that provide feeding, nesting, refuge and breeding grounds for the birds. From the foregoing findings, we can conclude that the ASALs of Baringo South offer ample habitat for a large number of bird species including the vulnerable Yellow necked spurfowl. The variations in various bird diversity indices can be attributed to the observed heterogeneity of habitats in the study area. We recommend wise use of rangeland resources and protection of critical avian habitats within the ASALs. Efforts should be geared towards livelihoods diversification and empowerment of the Lake Bogoria communities. This will reduce the pressure on the wooded shrublands that is widespread in the study area.

\section{Keywords}

Habitat, Avian Diversity, Extinction, Acacia Woodlands, Rangelands

\section{Introduction}

Tropical terrestrial ecosystems are acknowledged for harboring high diversity of avifauna with many coexisting species within habitat types [1]. They provide habitats for approximately $75 \%$ of all bird species whereas $45 \%$ of all bird species occur within humans modified habitats [2]. Semi-arid wooded shrublands are important and critical habitats that provide breeding and feeding grounds for a variety of bird species, some of which are endangered or threatened with extinction. Habitat type and size influence abundance and diversity of birds globally and particularly in developing countries that are characterized by rapid human population growth and haphazard urban, agricultural and industrial development. Birds are habitat-specific and some can occupy more than one habitat type. However, because of land-use changes, most of the birds have been displaced from their original habitats [3]. Nevertheless, human-dominated and agricultural habitats vary a lot from arid and semi-arid lands and therefore the effect on birds can be very different [4].

Birds are important environmental indicators besides their role in seed dispersal, recreation and education [5] [6]. They are diverse and widely distributed globally and are used to integrate a set of ecological factors within a given region [7] [8]. Thus the diversity and abundance of birds are strongly linked to the integrity, quality and diversity of habitats. Habitat deterioration will therefore lead to a reduction in abundance and diversity of avifauna. Despite being indicators of environmental change, birds are under pressure mainly from anthropogenic activities [9] [10] [11] that continue to influence negatively their feeding and breeding habitats. 
Habitat has a great influence on the abundance and diversity of birds globally and particularly in developing countries that are characterized by rapid human population growth and haphazard urban, agricultural and industrial development. Deforestation and human settlement are the main causes of habitat degradation and fragmentation [12]. Globally, there is evidence that semi-arid lands face many natural and anthropogenic challenges: overexploitation of natural resources, climate change, water scarcity and habitat degradation [11] [13] [14] [15]. Habitat size and characteristics are important predictors of diversity richness and abundance of birds [16]. Within the arid and semi-arid lands (ASALs] are a wide range of avifauna habitats, some of which are facing adverse climate change and pressure from anthropogenic activities. ASALs tend to be sparsely populated providing adequate habitat for breeding, perching and feeding sites for a number of bird species.

A number of studies (e.g. [17] [18]) have shown that habitat loss and degradation are the main drivers of biodiversity decline globally. The negative impacts of habitat degradation on bird species abundance and diversity within the tropical ecosystems have been documented by [19] [20] [21]. Declines in bird populations in the arid and semi-arid lands (ASALs) have been linked to unplanned development, climate change and urbanization [11]. The conservation of avifauna requires documentation of their habitats and diversity. There is however limited knowledge on bird diversity, abundance and distribution as well as existing natural and anthropogenic threats to conservation of birds in unprotected areas such as semi-arid lands of Baringo South.

The semi-arid lands of Baringo South are an environmentally and biologically heterogeneous ecosystem that makes a huge contribution to the conservation of global and regional biodiversity. However, the region is facing many threats that include illegal logging, slushing and burning for agriculture, infrastructure development projects and human settlements. The major conservation concern in the study area is the growing encroachment and conservation into the wooded bushlands/shrublands where many of the internally displaced persons (IDP's) have settled hence exerting immense pressure on the environment as they eke a living by extracting wood for construction, fencing and charcoal burning. Valuable large trees (mostly Acacia tortilis, Acacia elatior, Acacia nilotica) and endangered trees like sandalwood (Osyris lanceolata) are being extracted for charcoal, carving industry and medicines. Owing to the foregoing scenario, there is widespread habitat fragmentation and land degradation that directly and indirectly affect avifauna. The study area is also in close proximity to Lake Bogoria, a Ramsar site, a World Heritage Site as well as an Important Bird Area, and thus constitute a dispersal area for animals including birds from the Lake Bogoria National Reserve.

It is against this background that this study was conceptualized. It provides information on birds' conservation status, abundance and diversity in the different habitats found in Chemeron, Baringo South wooded shrublands. The study on diversity, distribution and abundance of birds with respect to different 
habitat types is important since it will provide an understanding on the avifauna diversity, distribution and abundance within natural and human occupied habitats. The study was guided by four questions: What kind of Habitat types are present at Chemeron study area? What kind of birds are found at Chemeron area? What is the conservation status of birds are found at Chemeron area? What are the functional feeding guilds of birds that are found in the study area? How does the habitat type influence bird species abundance and diversity at Chemeron?

\section{Methodology}

\subsection{Description of Study Area}

The study site is located within the Chemeron Dryland Research Training and Ecotourism Centre (Figure 1), which is approximately $120 \mathrm{~km}$ northwest of Nakuru town. It is approximately $11 \mathrm{~km}$ from Marigat town, and $2 \mathrm{~km}$ off the Marigat-Kabarnet road, in Baringo County. It is located within Agro-Ecological Zone $\mathrm{V}$ and receives an annual rainfall of about $635 \mathrm{~mm}$ that falls mainly in the months of April through June. The short rains occur in the months of October to November. The altitude at the study site is $1200 \mathrm{~m}$ above sea level. The soils are reddish brown, sandy loam with many rocky outcrops that makes it unsuitable for the growth of many of the commercial food crops in Kenya (e.g. Maize, wheat, tea, coffee, etc. The ground has a gentle slope and drains into the Chemeron River, a seasonal river that drains into Lake Baringo via the Perkerra River.

The vegetation in the study area is mainly dominated by different species of acacia, among them Acacia mellifera, Acacia tortilis, Acacia reficiens, Acacia brevispica and Acacia senegal. Other trees and shrubs in the study area include: Boscia anguistifolia, Balanites aegyptiaca, Grewia bicolor, Terminalia brownii, Maerua angolensis, Acalypha fruticosa and Berchemia discolour. The main grass species in the area include Aristida keniensis, Chloris roxburghiana and Eragrostis superba. The soils are not well developed and thus the prevalence of agropastoralism characterized by beekeeping goats and cattle production as the preferred animal species. The growing of commercial crops is inhibited by the dry, rocky and shallow sandy soil conditions. The area is however suitable for the cultivation of drought tolerant crops including finger and pearl millet, pigeon peas, vegetables and fruit crops such as mangoes, paw paws and lemons.

The main habitat types were: woodlands, shrublands, grasslands dominated by different species of acacias, shrubs and grass. Examples of these plant species include Acacia mellifera, Acacia tortillis, Balanites aegiptica, and Acalypha fruiticosa, among others (Table 1).

\subsection{Research and Sampling Design}

We used both quantitative and qualitative bird survey techniques to collect data on species list diversity and abundance. Line transects are considered suitable for bird surveys [22] [23] [24]. Six transects measuring 0.5 to $2.5 \mathrm{~km}$ in length, and 


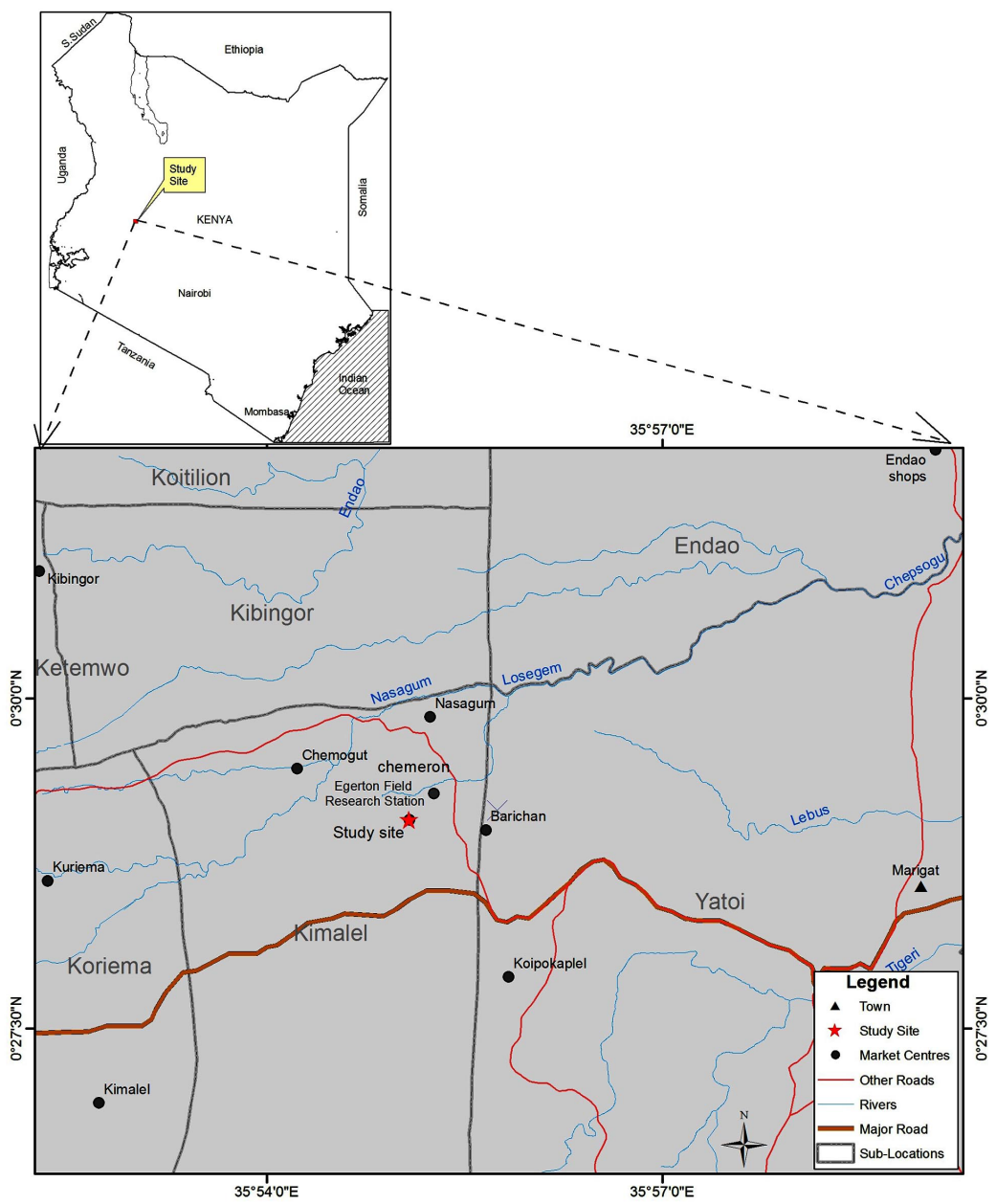

Figure 1. Map of Baringo South sub-county (Map of Kenya inset) showing the study site (Chemeron).

Table 1. The start and end GPS coordinates as well as the dominant habitat types at Chemeron, Baringo south.

\begin{tabular}{|c|c|c|c|}
\hline \multirow{2}{*}{ Transect Name } & \multicolumn{2}{|c|}{ GPS Coordinates } & \multirow{2}{*}{ Dominant Habitat Types } \\
\hline & Start & End & \\
\hline \multirow{2}{*}{ Transect 1} & $825,219.16 \mathrm{E}$ & $825,210.39 \mathrm{E}$ & Acacia senegal shrubland \\
\hline & $54,191.40 \mathrm{~N}$ & $53,849.78 \mathrm{~N}$ & Modified habitat (human settlement) \\
\hline \multirow{2}{*}{ Transect 2} & $825,210.31 \mathrm{E}$ & $825,330.21 \mathrm{E}$ & Acacia tortilis woodland \\
\hline & $54,048.81 \mathrm{~N}$ & $54,182.23 \mathrm{~N}$ & Acacia senegal shrubland \\
\hline \multirow{2}{*}{ Transect 3} & $825,178.98 \mathrm{E}$ & $825,411.26 \mathrm{E}$ & Acacia senegal shrubland \\
\hline & $53,917.46 \mathrm{~N}$ & $53,981.20 \mathrm{~N}$ & Boscia angustifolia wooded shrubland \\
\hline \multirow{2}{*}{ Transect 4} & $825,186.47 \mathrm{E}$ & $824,356.63 \mathrm{E}$ & Acacia tortilis woodland \\
\hline & $54,206.04 \mathrm{~N}$ & $53,691.35 \mathrm{~N}$ & $\begin{array}{c}\text { Acacia senegal-Balanites aegyptica } \\
\text { wooded shrubland }\end{array}$ \\
\hline \multirow[b]{2}{*}{ Transect 5} & $825,352.85 \mathrm{E}$ & $824,962.57 \mathrm{E}$ & Acalypha fruticosa shrubland \\
\hline & $54,208.43 \mathrm{~N}$ & $\begin{array}{l}024,902.3 / \mathrm{L} \\
54,940.19 \mathrm{~N}\end{array}$ & $\begin{array}{c}\text { Acacia elatior-Balanites aegyptica } \\
\text { woodland }\end{array}$ \\
\hline \multirow{3}{*}{ Transect 6} & & & Acacia tortilis woodland \\
\hline & $825,379.98 \mathrm{E}$ & $825,8 / 1.57 \mathrm{E}$ & Acacia reficiens woodland \\
\hline & $54,165.65 \mathrm{~N}$ & $52,312.79 \mathrm{~N}$ & Acacia senegal wooded shrubland \\
\hline
\end{tabular}


radiating from a central point within the study area were selected for a ground survey of birds that was conducted on foot. Owing to increased bird activity in the early morning and late afternoon [25], the surveys were conducted between $0630 \mathrm{hrs}$ and $0930 \mathrm{hrs}$ and $1600 \mathrm{hrs}$ and $1800 \mathrm{hrs}$ from October 2019 to April 2020. Observers walked slowly along the transects recording in a field notebook (bird census check lists), all birds seen or heard within the survey area. Additionally, we recorded basic survey parameters and habitat environmental variables at the beginning of each count. These included broad habitat type, human activity, date, start and end GPS coordinates of the transect (Table 1). Observers familiar with the Chemeron study area walked along each transect, stopping every time they spotted a bird (s) and after waiting for 2 min settling period, recorded all bird species encountered at the site within a 10-minute period. Bird species were observed and identified to the species level using high-resolution binoculars, field guidebooks [26] [27] and available taxonomic keys. Further, we used the IUCN 2016 Red Data List to understand the conservation status of birds encountered in our study. The local threats to the conservation of avifauna were also recorded.

\section{Data Analysis}

Prior to any statistical analyses, the data on bird counts were tested for normality and homogeneity of variance using the Kolmogorov-Smirnov Normality Test $(p>0.15)$ and Levene's Test for equal variances $(p>0.05)$, respectively. Upon satisfying the basic normality and homogeneous variance assumptions, we used both one-way and two-way analysis of variance (ANOVA) to test for differences in diversity and abundance amongst the various sites with alpha set at 0.05 [28] [29]. Various diversity indices including Simpson Species Diversity Index, DS [30], Shanon-Weiner's Evenness Index H' [31], and Jaccard's Similarity Coefficient JSC [32] were calculated. The formula for calculating the indices are given here below:

Shannon-Weiner diversity index

$$
\left(H^{\prime}\right)=H=\Sigma[(p i) \times \ln (p i)]
$$

where-pi: proportion of total sample represented by species $i$.

Species richness was calculated using the equation below:

$$
\begin{gathered}
\text { Maximum number of species, } H_{\max }=\ln (S) \\
\text { Equability(evenness) index }(J)=\frac{H^{\prime}}{H_{\max }}=-\sum i P i \frac{\operatorname{Ln}(p i)}{\operatorname{Ln}(S)}
\end{gathered}
$$

The relative abundance (RAI) was calculated as described in Singh and Rai (2001) whereas Frequency and Species Distribution Ratio were calculated as described in Cottam and Curtis (1956). The formulae are provided here blow:

$$
\text { Relative abundance } A=a / N * 100
$$

where $a=$ total population of a particular species.

$N=$ total population. 


$$
F=(F)=m * 100 / M
$$

where

$m=$ occurrence of species in samples.

$M=$ total number of samples.

$$
\text { Species Distribution Ratio(SDR })=\text { Abundance/Frequency . }
$$

\section{Results and Discussion}

The habitat types in the study area are shown on Table 1 . The common ones among the 6 transects include; Acacia Senegal shrubland and Acacia Tortilis woodland. Transect 5 was dominated by the invasive Acalypha fruticosa shrub and had few tall trees. Other main habitat types include: Acacia-Balanites-Boscia woodlands dominated by Acacia senegal, Acacia mellifera, Acacia nilotica, Boscia angustifolia, and Balanites aegyptica, and Acacia reficiens-Acacia brevispica wooded shrublands. Over $24 \%$ of the bird species in this avifaunal survey were found in the acacia woodlands (Figure 2). Nine percent of them were encountered in the open range country feeding on insects.

Studies by [33] and [34] attest to the importance of woodlands and shrublands as habitats for avian communities providing food and cover for different bird species. Decrease in abundance and diversity of birds has been attributed to charcoal burning, and other land degradation processes that lead to habitat loss [35] [36] [37]. Such land degradation leads to a reduction in the quality and quantity of cover, food resources and breeding sites that subsequently causes declines in species abundance and diversity.

The current study findings are similar to those of [38] that point to the significance of ASALs as crucial habitats for avian communities and thus the need for their conservation. Such conservation of biodiversity requires adequate information on abundance, diversity and distribution of the bird species as well as quantity and quality of habitats present. Design and implementation of effective management programmes are crucial for the long-term conservation of avian communities.

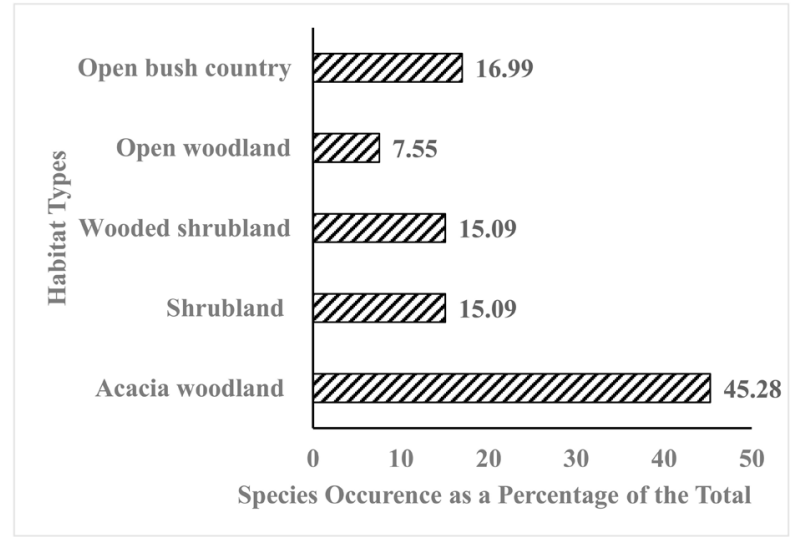

Figure 2. Number of bird species observed in various habitat types at Chemeron, Baringo South. 
There were 27 families in the current avifaunal survey. The dominant families included Columbidae, Estrildidae, Nectariniidae and Ploecidae representing $14.8 \%, 11.1 \%, 9.3 \%$ and $7.4 \%$, respectively (Figure 3 ). Approximately $80 \%$ of the birds were sighted as singles and/or in pairs except for the gregarious white browed sparrow weaver (Plocepasser mahali), Apus caffer, Numida meleagris, and Dinemellia dinemelli. Similar observations were made by [38] [39] where Numida meleagris displayed their gregarious behavior during feeding. Their social behavior may also be antipredator defense strategy. Birds from surveyed area of approximately $50 \%$ of the total area of 1100 acres of land belonging to DRTEC, Egerton University.

In terms of abundance, the gregarious Plocepasser mahali, was the most abundant species followed by Apus caffer, Numida meleagris, Streptopelia senegalensis, Dinemellia dinemelli and Corythaxoides leucogaster in that order (Table 2 ). In terms of frequency, $30 \%$ of the bird species were encountered in the six study transects (Table 2) indicating an even distribution in the range. In this study, Species Distribution Ratio exhibited a similar trend as for abundance with Apus caffer having the highest Species Distribution Ratio (SDR) value followed by $P$. mahali, $N$. meleagris, $S$. senegalensis and $D$. dinemelli in that order (Table 2 ). The current study findings are consistent with those of [40] that concluded that human-disturbed areas provide diverse habitats that are preferred by human tolerant species such as Ploceus mahali, Lamprotonis superba, Columba guinea and Streptopelia decipiens as observed in the study.

There were slight variations among transects in terms of species richness with the highest number of species encountered in transect 2 followed by 1 and 6 in that order (Figure 4). Variations in species diversity, richness and abundance have largely been attributed to vegetation composition that also directly influences availability of food, shelter and nesting sites that are crucial for survival and reproduction of birds [39].

According to [41] bird species diversity is less in human-activity areas with higher woodland and shrub cover and it is also low in areas affected by land use change. These observations are contrary to our study findings in which variations in bird species diversity amongst the study sites (areas with human settlements and complex habitat types) were not significant (Figure 5). Though the Shannon-Weiner Diversity Index was high in habitats with less human disturbance such as Acacia woodlands and Acalypha fruticosa shrublands the differences were not significant. Evenness diversity indices were relatively similar amongst all study transects the least values observed in Transect 4 (Figure 5).

The current study findings showed that most bird species e.g. Weavers, Starlings, doves and White bellied go away bird occurred in all transects with only a few limited to one or two transects in the study area. In the study of [42] weather and habitat conditions influence diversity of avifauna by spatial temporal shift of species from one habitat to the other seeking for favorable conditions. Owing to similarity in weather conditions and close resemblance of the habitats, it is no 
surprise then that variations in species diversity, abundance and distribution are minimal. Our study was conducted during the rainy season resulting to high diversity of bird species across the transects (Figure 5). Further, resident bird species in arid areas (for example the White-bellied go away bird) are physiologically and behaviorally adapted to survive under unpredictable environmental conditions [43] [44].

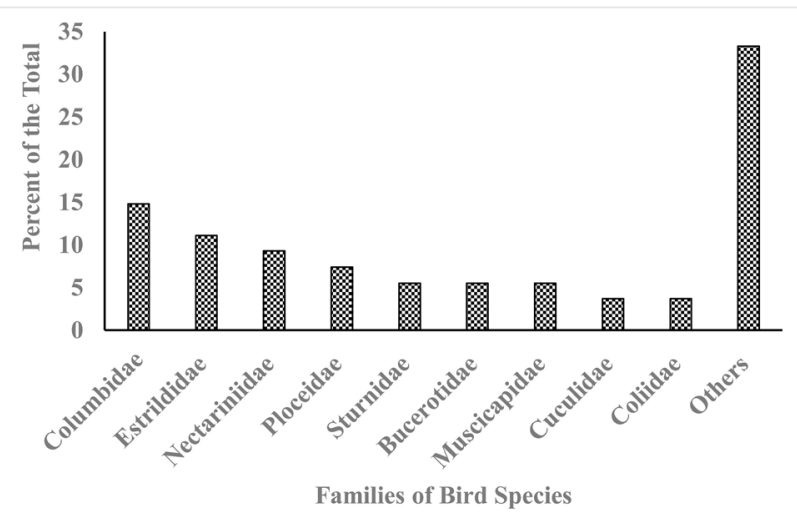

Figure 3. Percent family representation for various bird species at Chemeron, Baringo South.

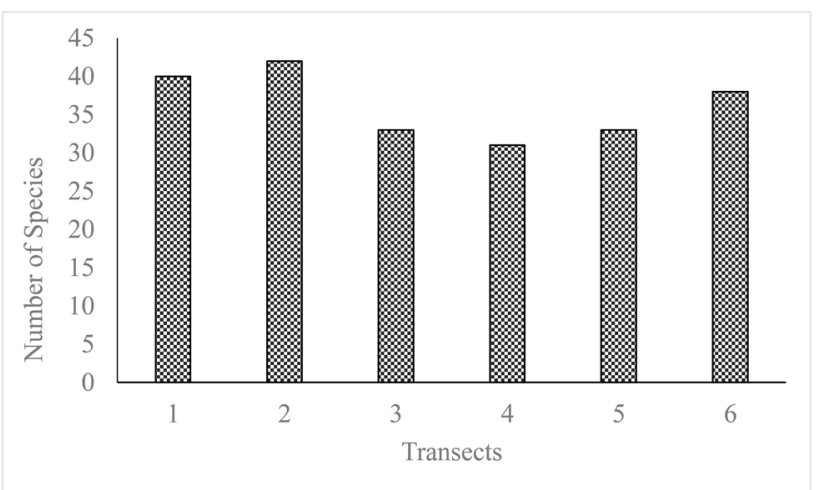

Figure 4. Species richness for birds encountered in an Avifaunal survey at Chemeron, Baringo South.

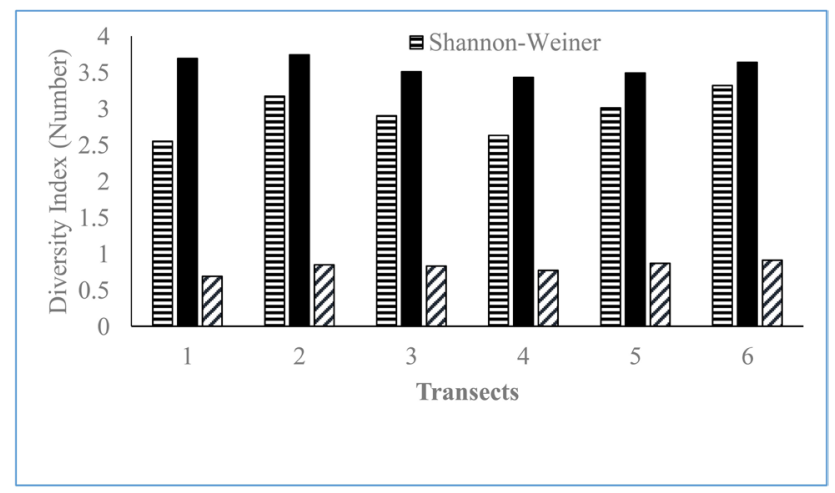

Figure 5. Species diversity indices for birds encountered in an Avifaunal survey at Chemeron, Baringo South. 
Table 2. Abundance, frequency and species distribution ratio of various bird species encountered during an avifaunal survey at Chemeron, Baringo South. SDR denotes species distribution ratio. LC: Least Concern; VU: Vulnerable as per IUCN Red Data List.

\begin{tabular}{|c|c|c|c|c|}
\hline Scientific Name & Common Name & Abundance & Frequency & SDR \\
\hline Apus caffer ${ }^{L C}$ & White rumped swift & 14.56 & 83.33 & 0.17 \\
\hline Anaplectes melanotis ${ }^{L C}$ & Red headed weaver & 0.20 & 33.33 & 0.01 \\
\hline Anaplectes rubriceps ${ }^{L C}$ & Black headed weaver & 3.26 & 100.00 & 0.03 \\
\hline Batis molitor ${ }^{L C}$ & Chin spot flycatcher & 0.13 & 16.67 & 0.01 \\
\hline Buphagus erythrorhynchus ${ }^{L C}$ & Red billed oxpecker & 1.04 & 33.33 & 0.03 \\
\hline Cecropis daurica ${ }^{L C}$ & Red rumped swallow & 0.65 & 66.67 & 0.01 \\
\hline Chalcomitra amethystina ${ }^{L C}$ & Amethyst sunbird & 1.04 & 100.00 & 0.01 \\
\hline Dendropicos namaquus ${ }^{L C}$ & Bearded woodpecker & 0.13 & 33.33 & 0.00 \\
\hline Colius macrourus ${ }^{L C}$ & Blue napped mousebird & 0.85 & 66.67 & 0.01 \\
\hline Colius striatus ${ }^{L C}$ & Speckled mousebird & 1.89 & 100.00 & 0.02 \\
\hline Columba guinea ${ }^{L C}$ & Speckled pigeon & 0.72 & 66.67 & 0.01 \\
\hline Coracias naevia ${ }^{L C}$ & Rufous crowned roller & 0.52 & 66.67 & 0.01 \\
\hline Corvus albus ${ }^{L C}$ & Pied crow & 0.46 & 33.33 & 0.01 \\
\hline Corythaixoides leucogaster ${ }^{L C}$ & White bellied go away bird & 3.46 & 100.00 & 0.03 \\
\hline Cuculus solitarius ${ }^{L C}$ & Red chested cuckoo & 0.59 & 83.33 & 0.01 \\
\hline Dicrurus adsimilis ${ }^{L C}$ & Drongo & 2.48 & 100.00 & 0.02 \\
\hline Dinemellia dinemelli $I^{L C}$ & White headed buffalo weaver & 4.44 & 100.00 & 0.04 \\
\hline Empidornis semipartitus ${ }^{L C}$ & Silver bird & 0.72 & 33.33 & 0.02 \\
\hline Uraeginthus ianthinogaster ${ }^{L C}$ & purple grenadier & 0.85 & 66.67 & 0.01 \\
\hline Lagonostica larvata ${ }^{L C}$ & Black faced firefinch & 0.52 & 50.00 & 0.01 \\
\hline Lagonosticta senegala ${ }^{L C}$ & Red billed firefinch & 2.22 & 100.00 & 0.02 \\
\hline Lamprotornis purpuroptera ${ }^{L C}$ & Ruppells starling & 1.89 & 100.00 & 0.02 \\
\hline Malaenornis pammelaina ${ }^{L C}$ & South African flycatcher & 2.02 & 100.00 & 0.02 \\
\hline Melaenornis fischerit ${ }^{2 C}$ & White eyed slaty flycatcher & 0.85 & 100.00 & 0.01 \\
\hline Nectarinia hunteri ${ }^{L C}$ & Hunters sunbird & 0.72 & 100.00 & 0.01 \\
\hline Nectarinia johnstoni $I^{L C}$ & Red tufted sunbird & 0.46 & 83.33 & 0.01 \\
\hline Nectarinia tacazze $e^{L C}$ & Tacazze sunbird & 0.65 & 83.33 & 0.01 \\
\hline Numida meleagris ${ }^{L C}$ & helmeted guinea fowl & 11.49 & 100.00 & 0.11 \\
\hline Oena capensis ${ }^{L C}$ & Namaqua dove & 0.46 & 33.33 & 0.01 \\
\hline Onchognathus morio ${ }^{L C}$ & Red winged starling & 0.65 & 50.00 & 0.01 \\
\hline Oriolus larvatus ${ }^{L C}$ & Black headed oriole finch & 0.52 & 83.33 & 0.01 \\
\hline Passer griseus ${ }^{L C}$ & Grey headed sparrow & 1.31 & 83.33 & 0.02 \\
\hline Phoeniculus purpureus $s^{L C}$ & Green wood hoopoe & 1.70 & 66.67 & 0.03 \\
\hline Plocepasser mahali ${ }^{L C}$ & White browed sparrow weaver & 17.17 & 100.00 & 0.17 \\
\hline Poicephalus meyerit ${ }^{L C}$ & Brown parrot & 1.11 & 50.00 & 0.02 \\
\hline
\end{tabular}




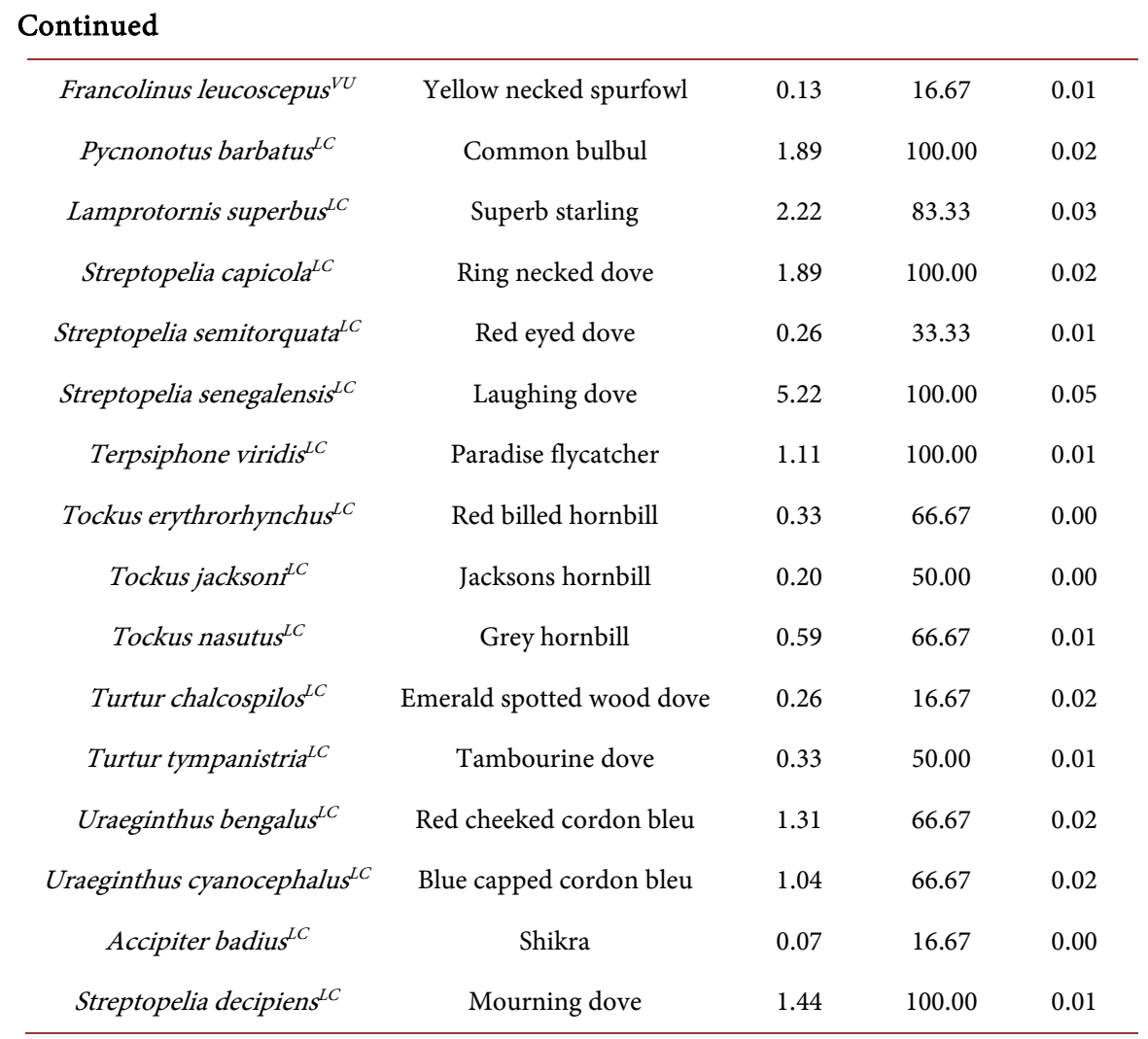

A study by [45] showed that the bird species composition and distribution are influenced by temperature, relative humidity, light intensity) and habitat structure /vegetation cover, vegetation composition and distribution. These findings partially support our results that relate bird species diversity to habitat composition and distribution. The greater the volume of vegetation, the greater the abundance of passerine birds.

The Shannon-Weiner diversity index variations among the six transects exhibited a similar trend as for species richness with transects 2 and 6 having the highest values (Figure 5). With respect to evenness Index (J), similar trends as for abundance and Shannon-Weiner Index were observed with the lowest valued being in transect 1 (Figure 5). Similar observations were made for the H' max (maximum diversity possible). In terms of Shannon-Weiner Diversity indices, our results are consistent with those of [38] whose values ranged from 2.16 to 2.89 .

Over $95 \%$ of the species in this birds' survey belong to the Least concern category of the IUCN 2016 Red Data List. There was one bird species, the Yellow necked spur fowl (Francolinus leucoscepus/Pternistis leucoscepus), a dry bush country bird species that is classified as Vulnerable as per the IUCN Red Data List [46].

There were significant differences in species richness $(\mathrm{F}=11.29 ; \mathrm{p}<0.001)$, Shannon-Weiner Indiex $(\mathrm{F}=8.12 ; \mathrm{p}<0.001)$, H-Max $(\mathrm{F}=4.62 ; \mathrm{p}<0.01)$, and evenness $(\mathrm{F}=22.79 ; \mathrm{p}<0.001)$ among the six transects. 
The high diversity of bird species in the study area can be attributed to the varied diversity of habitats that provide feeding, nesting, refuge and breeding grounds for the birds. From the foregoing findings, we can conclude that ASALs offer ample habitat for birds including some of which face global extinction. The avifauna assemblages differed according to broad habitat types. A greater number of nectarivores and insectivores and woodland-dependent species were abundant in dryland forest habitats. Acacia woodlands had the highest numbers of omnivores and insectivores while wooded shrublands had the highest number of granivores, nectarivores and frugivores.

Our results are consistent with those of [11] where the dominant feeding guilds were the insectivores followed by carnivores, omnivores, granivores, gruvivores and nectarivores in that order. Similar observations were made by [23] [47] [48]. Further, our results are consistent with those from 43 (https://doi.org/10.1006/jare.2001.0910) that showed that bird communities in Acacia dominated woodlands were more diverse and species-rich than those for the invasive Prosopis sites.

Our study revealed that approximately $60 \%$ of the birds in this survey belong to the insectivore and omnivore functional feeding guilds (Figure 6). The other fairly common feeding group was frugivores that constituted $23 \%$ of the total species encountered. The highest feeding guild recorded was insectivores 32\% species compared to others (Figure 6). However, in terms of functional feeding guilds, our study yielded different results compared to those of [43]

(https://doi.org/10.1006/jare.2001.0910). In the current study insectivorous constituted $80 \%$ of the birds whereas $20 \%$ constituted of frugivores, granivores and nectarivores. No raptors were recorded in any of the habitats during this study.

The bird species were more evenly distributed in woodlands than the shrublands. The dominant bird species were white browed sparrow weaver (Plocepasser mahali), superb starling (Lamprotornis superbus), mourning dove (Streptopelia decipiens), red billed fire finch (Lagonosticta senegala), speckled mouse bird (Colius sriatus), white bellied go away bird (Corythaixoides leucogaster), and laughing dove (Streptopelia senegalensis).

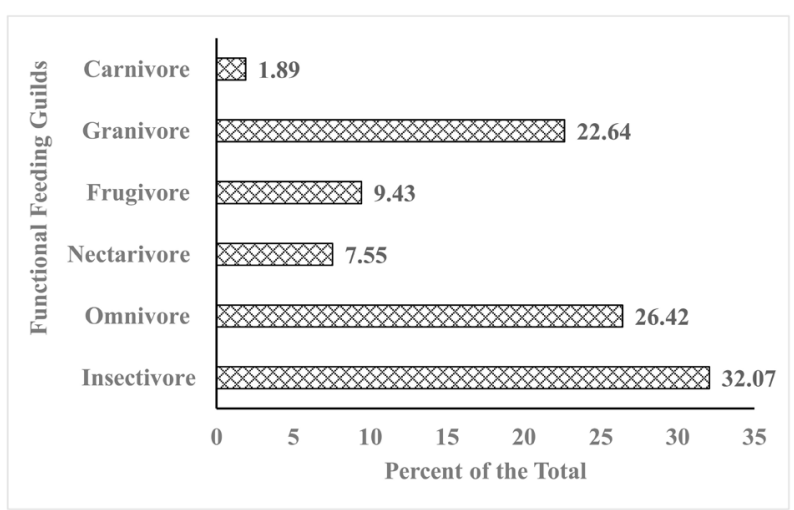

Figure 6. Functional feeding guilds for birds encountered in Avifaunal survey at Chemeron, Baringo South. 
Acacia woodlands mainly consisting of Acacia Senegal, A. mellifera, A. reficiens, $A$. nilotica, A. brevispica and $A$. tortilis were dominated by just a few bird species. Similar observations were made by [49]. Our results exhibit lower species evenness compared to those of [49]. This could be attributed to the fact that forests have higher species evenness owing to the many microhabitats compared to those found in arid and semi-arid lands. Acacia woodlands are characterized by uneven distribution of species. They also showed little similarity with other habitat types. Woodland birds show relatively poor relations with habitat classification [50]. Feeding guilds are related or partly dependent on the variation in vegetation structure of an ecosystem. Instead, a majority of studies have found a positive correlation between habitat heterogeneity and bird species diversity [51]. It can safely be observed that forests support larger and many feeding guilds where dominant species have lower species richness compared to those in ASALs. Diversity, abundance, and distribution of birds may also be affected by habitat fragmentation and a variety of unsustainable anthropogenic activities. In our study area, variations in avian diversity, abundance and distribution may be explained by deforestation, human settlements, infrastructure development, and expansion of agricultural lands. Similar observations have been made by [52] and [38] in which bird species diversity and abundance were affected by deforestation, firewood collection and overgrazing. Such anthropogenic activities pose negative impacts on available food and water resources. They also negatively affect nesting and refuge sites for the birds.

Study findings by Balmford and others [53] revealed that across sub-Saharan Africa, patterns of species richness and human population density exhibit marked congruence; high values of species richness are encountered in areas of high human population density. From their study, bird richness generally correlated positively with high human population. Our study findings are similar to those of [54] that demonstrate that many bird species inhabiting scrub habitats are sensitive to human habitat transformation. Thus, fragmentation and conversion of arid and semi-arid lands into human settlements and agricultural lands affect the diversity and abundance of scrub habitat bird species. It is no surprise that human transformation of habitats has been singled out as one of the leading driving factors influencing distribution and abundance of terrestrial avifauna [54]. It has been observed that the avian community can benefit from small but not large drastic habitat changes since the former create new habitats and conditions that benefit a variety of birds. Such changes are deemed not capable of fragmenting habitats and/or isolating bird populations. Only species that are selective scrub dwellers may be negatively affected by extensive habitat changes. It has been shown that common birds such as Streptopelia decipiens, Lamprotornis superbus, and Lagonostica senegala benefit from such transformation of habitats. These bird species are associated with human activity for breeding and feeding and therefore high in abundance and diversity in and around human settlements. In spite of the preceding observations, rare, endangered, endemic and threatened species are likely to be adversely affected by anthropogenic activ- 
ities that transform their habitat. Such transformations are likely to negatively their populations due to declines in food resources, and quality and quantity of breeding and refuge areas.

Seven migrant species were observed during this survey ranging from the Inter-tropical Oena capensis to the Intra-African migrant, Cuculus solitarius (Table 3). The other migrant species included Poicephalus meyeri, Nectarinia tacazze, Cecropis daurica and Apus caffer. As a stopover site for migrants, the Chemeron area supports three species (Cecropis daurica, Cuculus solitarius and Poicephalus meyeri) that move through Kenya [55]. Seasonal availability of resources caused by changing precipitation patterns as well as through genetic influences play a role in species diversity patterns by influencing species composition across the study area [56].

\section{Conclusions and Recommendations}

From the foregoing findings, we can conclude that the ASALs of Baringo offer ample habitat for a large number of birds including the vulnerable Yellow necked spurfowl (Francolinus leucoscepus). The insignificant variations in bird species diversity can be attributed to similarity and close proximity of habitats. Human transformation of habitats favoured some of the species and thus the observed large numbers of Streptopelia decipiens, Lamprotornis superbus, Lagonostica senegala, Plocepasser mahali, Apus caffer, Numida meleagris, Streptopelia senegalensis, and Dinemellia dinemelli. The most dominant feeding guilds were insectivorous and omnivorous groups that are largely explained by the type of food and habitats found in the study area. We recommend wise use of rangeland resources and protection of critical avian habitats within the ASALs. The study area as well as adjacent lands to Lake Bogoria National Reserve (a Ramsar Site, a World Heritage Site and an Important Bird Area) should be given priority in terms of conservation given that they serve as dispersal areas for wild animals including birds. Appropriate avian management actions based on the data contained in this paper and similar research works should be undertaken to ensure that avian habitats are well conserved. Efforts should be geared towards

Table 3. Migratory bird species observed at chemeron, baringo south. Classification by migratory status of the birds.

\begin{tabular}{ccc}
\hline Bird Species & Common Name & Migratory Status \\
\hline Poicephalus meyeri & Brown parrot & Migrant \\
Oena capensis & Namaqua dove & Inter-tropical migrant \\
Nectarinia tacazze & Tacazze sunbird & Migrant \\
Cuculus solitarius & Red chested cuckoo & Intra-African migrant \\
Chalcomitra amethystina & Amethyst sunbird & Partial migrant \\
Cecropis daurica & Red rumped swallow & Migrant \\
Apus caffer & White rumped swift & Migrant \\
\hline
\end{tabular}


biodiversity conservation and livelihoods diversification and enhancement for the Lake Bogoria communities. This will reduce the pressure on the natural resource extraction through unsustainable land-use practices that is characteristic of the study area.

\section{Acknowledgements}

The authors of this manuscript want to express their deep and heartfelt appreciation to the staff and research team at the Egerton University's Dryland Research Training and Ecotourism Centre (DRTEC) at Chemeron for their support all through the study. We are grateful to Mr. Geoffrey Maina of Egerton University's Department of Environmental Science for his support in drawing the study area map that has been used in this manuscript. Last but not least, we are grateful to the various reviewers of this paper for their valuable comments and feedback.

\section{Conflicts of Interest}

The authors declare no conflicts of interest regarding the publication of this paper.

\section{References}

[1] Jankowski, J.E., Ciecka A.L., Meyer, N.Y and Rabenold, K.N. (2009) Beta Diversity along Environmental Gradient: Implications of Habitat Specialization in Tropical Montane Landscapes. Journal of Animal Ecology, 78, 315-327. https://doi.org/10.1111/j.1365-2656.2008.01487.x

[2] Bird Life International (2008) Birds Occur in All Major Habitat Types, with Forest Being Particularly Important. Presented as Part of the Bird Life State of the World's Birds Website. http://www.birdlife.org/datazone/sowb/casestudy/172

[3] Burgess, N.D., Doggart, N. and Lovett, J.C. (2002) The Uluguru Mountains of Eastern Tanzania: The Effect of Forest Loss on Biodiversity. Oryx, 36, 140-152. https://doi.org/10.1017/S0030605302000212

[4] Tworek, S. (2002) Different Bird Strategies and Their Responses to Habitat Changes in an Agricultural Landscape. Ecological Research, 17, 339-359. https://doi.org/10.1046/j.1440-1703.2002.00493.x

[5] Martin, T.E. (1992) Breeding Productivity Considerations: What Are the Appropriate Habitat Features for Management? In: Hagan, J.M. and Johnston, D.W., Eds., Ecology and Conservation of Neotropical Migrant Landbirds, Smithson Institude Press, Washington DC, 475-473.

[6] Altwegg, R., Wheeler, M. and Erni, B. (2008) Climate and the Range Dynamics of Species Abundance and Exploitation of Food Resources. Ecology, 6, 2295-2309.

[7] Lawton, J.H., Bignell, D.E., Bolton, B., Bloemers, G.F., Eggleton, P., Hammond, P.M., Hodda, M., Holt, R.D., Larsen, T.B., Mawdsley, N.A., Stork, N.E., Srivastava, D.S. and Watt, A.D. (1998) Biodiversity Indicators, Indicator Taxa and Effects of Habitat Modification in Tropical Forest. Nature, 391, 72-76. https://doi.org/10.1038/34166

[8] Gregory, D.D. and Altwegg, R. (2018) Effectiveness of Protected Areas for Bird Conservation Depends on Guild. Diversity and Distributions, 24, 1-9. 
[9] Reed, J.M., Elphick, C.S., Leno, E.N. and Zuur, A.F. (2011) Long-Term Population Trends of Endangered Hawaiian Water Birds. Population Ecology, 53, 473-481. https://doi.org/10.1007/s10144-011-0262-9

[10] Mangesha, G., Yosef, M., Sahle, K., Elphick, C. and Bekele, A. (2014) Effects of Land Use in and around Lake Zeway, Ethiopia. Journal of Science and Development, 2, 5-22.

[11] Khan, I.D.Y. and Venkatesha, G.M. (2019) Avian Diversity of Semi-Arid Landscape: A Study from Chitradurga District, Karnataka, India. Environment and Ecology, 37, 1037-1049.

[12] Donald, P.F., Green, R.E. and Heath, M.F. (2001) Agricultural Intensification and the Collapse of Europe's Farmland Bird Populations. Proceedings of the Royal Society B: Biological Sciences, Vol. 268, 25-29. https://doi.org/10.1098/rspb.2000.1325

[13] Stattersfield, A.J., Crosby, M.J., Long, A.J., Wege, D.C. and Rayner, A.P. (2005) Endemic Bird Areas of the World: Priorities for Biodiversity Conservation. Bird Life International, Cambridge.

[14] Shin, S.H., Chung, I.U. and Kim, H.J. (2012) Relationship between the Expansion of Dry Lands and the Intensification of Hadley Circulation during the Late Twentieth Century. Meteorology and Atmospheric Physics, 118, 117-128. https://doi.org/10.1007/s00703-012-0220-x

[15] Souza, K.D., Kituyi, E., Harvey, B., Leone, M., Murali, K.S. and Ford, J.D. (2015) Vulnerability to Climate Change in Three Hot Spots in Africa and Asia: Key Issues for Policy-Relevant Adaptation and Resilience Building Research. Regional Environmental Change, 15, 747-753. https://doi.org/10.1007/s10113-015-0755-8

[16] Riffell, S.K., Keas, B.E. and Burton, T.M. (2003) Birds in North American Great Lakes Coastal Wet Meadows: Is Landscape Context Important? Landscape Ecology, 18, 95-111. https://doi.org/10.1023/A:1024411218155

[17] Brooks, T. and Thompson, H.S. (2001) Current Bird Conservation Issues in Africa. The Auk. Journal of Ornithology, 118, 575-582. https://doi.org/10.1093/auk/118.3.575

[18] Buchanan, G.M., Donald, P.F., Fishpool, L.D.C., Arinaitwe, J.A., Balman, M. and Mayaux, P. (2009) An Assessment of Land Cover and Threats in Important Bird Areas in Africa. Bird Conservation International, 19, 49-61. https://doi.org/10.1017/S0959270908007697

[19] Tilman, D. (2001) Functional Diversity. In: Levin, S.A., Ed., Encyclopedia of Biodiversity, Academic Press, Cambridge, 109-120. https://doi.org/10.1016/B0-12-226865-2/00132-2

[20] Kettle, C.J. (2014) Fragmentation Genetics in Tropical Ecosystems: From Fragmentation Genetics to Fragmentation Genomics. Conservation Genetics, 15, 1265-1268. https://doi.org/10.1007/s10592-014-0673-1

[21] Monkkonen, M., Rajasarkka, A. and Lampila, P. (2014) Isolation, Patch Size and Matrix Effects on Bird Assemblages in Forest Reserves. Biodiversity and Conservation, 23, 3287-3300. https://doi.org/10.1007/s10531-014-0780-9

[22] Sutherland, W.J. (2006) Ecological Census Techniques-A Hand Book. 2nd Edition, Cambridge University Press, Cambridge, UK.

[23] Rajashekara, S. and Venkatesha, M.G. (2015) Temporal and Spatial Avian Community Composition in Urban Landscapes of the Bengaluru Region, India. Journal of Environmental Biology, 36, 607-616.

[24] Rajashekara, S. and Venkatesha, M.G. (2017) Seasonal Incidence and Diversity Pattern of Avian Communities in the Bangalore University Campus, India. Proceed- 
ings of the Zoological Society, 70, 178-193. https://doi.org/10.1007/s12595-016-0175-x

[25] Bennun, L., Davies, C., Howell, K., Newing, H. and Linkie, M. (2002) African Forest Biodiversity: A Field Survey Manual for Vertebrates. Oxford, Eartwatch Europe.

[26] Zimmerman, D.A., Turner, D.A. and Pearson, D.J. (1999) Birds of Kenya and Northern Tanzania. Field Guide Edition, Princeton University Press, Princeton, NJ.

[27] Stevenson, T. and Fanshawe, J. (2002) Field Guide to the Birds of East Africa: Kenya, Tanzania, Uganda, Rwanda and Burundi. 1st Edition, Princeton University Press, Princeton.

[28] Sokal, R.R. and Rohlf, F.J. (1995) Biometry: The Principles and Practice of Statistics in Biological Research. 3rd Edition, W.H. Freeman, San Francisco, CA.

[29] Minitab 17 Statistical Software (2000) Compouter Software. Minitab, Inc., State College, PA. http://www.minitab.com/

[30] Simpson, E.H. (1949) Measurement of Diversity. Nature, 163, 688. https://doi.org/10.1038/163688a0

[31] Stiles, G. and Skutch, A. (1989) A Guide to the Birds of Costa Rica. Cornell University Press, Ithaca, NY.

[32] Fleiss, J.L. (1981) Statistical Methods for Rates and Proportions. 2nd Edition, John Wiley \& Sons, Hoboken.

[33] Askins, R.A., Folsom-Okeefon, C.M. and Hardly, M.C. (2012) Effects of Vegetation, Corridor Width and Regional Land Use on Early Successional Birds on Powerline Corridors. PLOS ONE, 7, e31520. https://doi.org/10.1371/journal.pone.0031520

[34] Shochat, E., Lerman, S. and Fernández-Juricic, E. (2010) Birds in Urban Ecosystems: Populations Dynamics, Community Structure, Biodiversity and Conservation. Urban Ecosystem Ecology, 55, 75-86. https://doi.org/10.2134/agronmonogr55.c4

[35] Frontier-Tanzania (2005) Uluguru Component Biodiversity Survey 2005 (Volume III): Uluguru North Forest Reserve. Bracebridge, C., Fanning, E., Howell, K.M., Rubio, P. and St. John, F.A.V., Eds., Society for Environmental Exploration and the University of Dar es Salaam; CARE-Tanzania, Conservation and Management of the Eastern Arc Mountain Forests (CMEAMF): Uluguru Component, Forestry and Beekeeping Divison of the Ministry of Natural Resources and Tourism, Dar es Salaam, Tanzania, 1-78.

[36] Doggart, N., Lovett, J., Mhoro, B., Kiure, J. and Burgess, N. (2005) Biodiversity Surveys in the Forest Reserves of the Uluguru Mountains. Technical Paper for the Wildlife Conservation Society of Tanzania and Tanzanian Forest Conservation Group. DSM, Tanzania, 8-18.

[37] Poulin, B., Lefebvre, G. and McNeil, R. (1992) Tropical Avian Phenology in Relation to Abundance and Exploitation of Food Resources. Ecology, 73, 2295-2309. https://doi.org/10.2307/1941476

[38] Kiros, S., Afework, B. and Legese, K.A. (2018) A Preliminary Study on Bird Diversity and Abundance from around Gubre Subcity and Wolkite Town, Southwestern Ethiopia. International Journal of Avian \& Wildlife Biology, 3, 333-340. https://doi.org/10.15406/ijawb.2018.03.00116

[39] Girma, Z., Yosef, M., Mangesha, G., Verma, A. and Asfaw, T. (2017) Seasonal Abundance and Habitat Use of Bird Species in and Around Wendo Genet Forest, South-Central Ethiopia. Ecology and Evolution, 7, 3397-3405. https://doi.org/10.1002/ece3.2926

[40] Clergeau, P., Savard, G., Mennechez, G. and Falardeau, G. (1998) Bird Abundance 
and Diversity along an Urban-Rural Gradient: A Comparative Study between Two Cities on Different Continents. The Condor, 100, 413-425. https://doi.org/10.2307/1369707

[41] Fahrig, L., Baudry, J., Brotons, L., Burel, F.G., Crist, T.O., Fuller, R.J., Sirami, C., Siriwardena, G.M. and Martin, J.-L. (2010) Functional Landscape Heterogeneity and Animal Biodiversity in Agricultural Landscapes. Ecology Letters, 14, 101-112. https://doi.org/10.1111/j.1461-0248.2010.01559.x

[42] Parmesan, C. (2005) Biotic Response: Range and Abundance Changes. In: Lovejoy, T.E. and Hannah, L., Eds., Climate Change and Biodiversity, Yale University Press, New Haven \& London, 41.

[43] Dean, W.R.J., Anderson, M.D., Milton, S.J. and Anderson, T.A. (2002) Avian Assemblages in Native Acacia and Alien Prosopis Drainage Line Woodland in the Kalahari, South Africa. Journal of Arid Environments, 51, 1-19. https://doi.org/10.1006/jare.2001.0910

[44] Simmons, R.E., Barnard, P., Dean, W.R.J., Midgley, G.F., Thuiller, W. and Hughes, G. (2004) Climate Change and Birds: Perspectives and Prospects from Southern Africa. Ostrich, 75, 295-308. https://doi.org/10.2989/00306520409485458

[45] Rajpar, M.N. and Zakaria, M. (2011) Bird Species Abundance and Their Correlationship with Microclimate and Habitat Variables at Natural Wetland Reserve, Peninsular Malaysia. International Journal of Zoology, 2011, Article ID: 758573. https://doi.org/10.1155/2011/758573

[46] IUCN (2016) Bird Life International. The IUCN Red List of Threatened Species 2016. http://www.iucnredlist.org/

[47] Gajera, N.B., Mahato, A.K.R. and Kumar, V.V. (2012) Birds in the Arid and Semi-Arid Forests of Kach: Its Status, Diversity and Composition. International Journal of Zoological Research, 2, 23-27.

[48] Sharma, N. and Kichloo, M.A. (2015) Avian Habitat-Use and Dietary Guilds in Different Forest Communities of Bhaderwah, Jammu and Kashmir, India. International Journal of Recent Scientific Research, 6, 5145-5149.

[49] Ng'weno, F., Baya, A., Mwinami, T. and Chesire, D.K.S. (2015) Bird Diversity Survey in the Boni-Dodori Forest Systems Kenya. https://www.researchgate.net/publication/319253680

[50] Woinarski, J.C.Z., Tidemann, S.C. and Kerin, S. (1988) Birds in a Tropical Mosaic-The Distribution of Bird Species in Relation to Vegetation Patterns. Australian Wildlife Research, 15, 171-196. https://doi.org/10.1071/WR9880171

[51] Tews, J., Brose, U., Grimm, V., Tielbörger, K., Wichmann, M.C., Schwager, M. and Jeltsch, F. (2004) Animal Species Diversity Driven by Habitat Heterogeneity/Diversity: The Importance of Keystone Structures. Journal of Biogeography, 31, 79-92. https://doi.org/10.1046/j.0305-0270.2003.00994.x

[52] Asefa, A., Davies, B.A., Mckechnie, E.A., Kinahan, A.A. and Vanresburg, J.B. (2017) Effects of Anthropogenic Disturbance on Bird Diversity in Ethiopian Montane Forests. The Condor, 119, 416-430. https://doi.org/10.1650/CONDOR-16-81.1

[53] Balmford, A., Moore, J.L., Brooks, T., Burgess, N., Hansen, L.A., Williams, P. and Rahbek, C. (2001) Conservation Conflicts Across Africa. Science, 29, 2616-2619. https://doi.org/10.1126/science.291.5513.2616

[54] Ricardo, R.E. (2007) Land Use Changes Affect Distributional Patterns of Desert Birds in the Baja California Peninsula, Mexico. Diversity and Distributions, 13, 877-889. https://doi.org/10.1111/j.1472-4642.2007.00387.x

[55] Bird Committee of the East Africa Natural History Society (2009) Checklist of the 
Birds of Kenya. Nairobi, Kenya.

[56] Signor, C.A. and Pinho, J.B. (2011) Spatial Diversity Patterns of Birds in a Vegetation Mosaic of the Pantanal, Mato Grosso, Brazil. Zoologia, 28, 725-738. https://doi.org/10.1590/S1984-46702011000600005 